\title{
INFLUENCE OF SHORT CHAIN FATTY ACIDS ON THE ABSORPTIVE CLEARANCE OF RANITIDINE HCI FROM RABBIT INTESTINE
}

\author{
Mohammed A. Osman
}

Department of Pharmaceutical Technology, College of Pharmacy,Tanta University, Tanta, Egypt, E. mail: mosman4444@yahoo.com

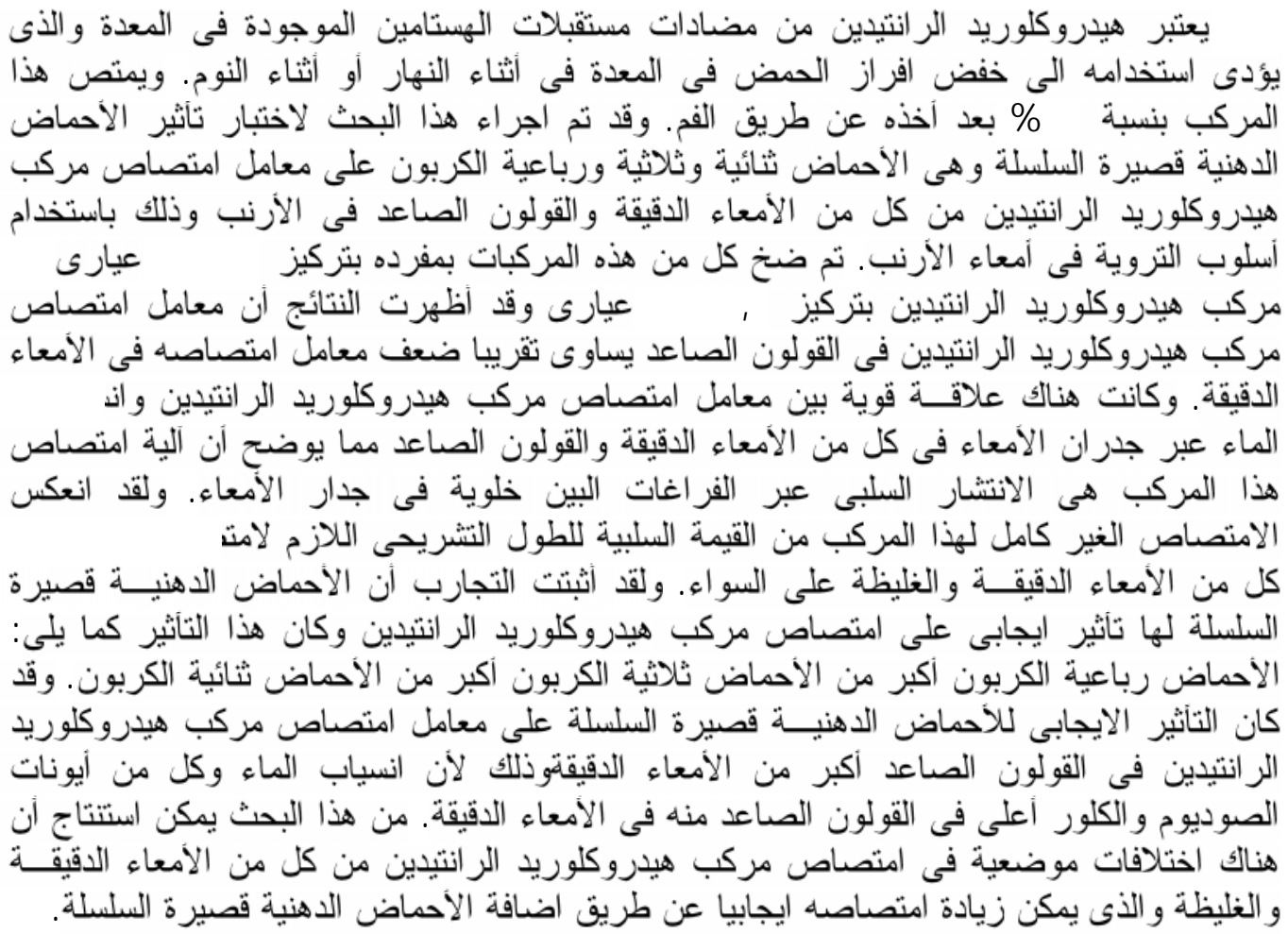

Ranitidine $\mathrm{HCl}$ is a histamine $\mathrm{H}_{2}$-receptor antagonist reducing gastric acid secretion under daytime and nocturnal basal conditions. Ranitidine $\mathrm{HCl}$ is $50 \%$ absorbed after oral administration. This research was undertaken in order to examine the effect of short-chain fatty acids (SCFAs), acetate, propionate, and butyrate on the absorptive clearance of ranitidine $\mathrm{HCl}$ as a function of intestinal site (jejunoileum vs ascending-colon). A "through-and-through" in situ intestinal perfusion technique was adopted using the rabbit as an animal model. Coperfusion of either sodium acetate, sodium propionate, or sodium butyrate, $25 \mathrm{mM}$ each, along with ranitidine $\mathrm{HCl}, 0.2 \mathrm{mM}$, allowed for an examination of increased solvent drag on intestinal permeability of this compound in both anatomical sites. The results show that ranitidine $\mathrm{HCl}$ is absorbed from rabbit jejunoileum as well as the ascending-colon, however the value of the absorptive clearance of this compound normalized to the intestinal length PeA/L in the ascending-colon was almost double that in the jejunoileum. A strong correlation was found between the absorptive clearance and the net water flux in both segments suggesting that the mechanism of ranitidine $\mathrm{HCl}$ absorption apparently consists of passive diffusion via the paracellular pathway. The negative value of anatomical reserve length ARL in both segments reflects the incomplete absorption of this compound. SCFAs had a significant effect on increasing the absorptive clearance of ranitidine $\mathrm{HCl}$ in both segments studied. This effect was in the order butyrate > propionate > acetate. However there was no statistical difference between the effect of butyrate and propionate. The permeability enhancing effect of SCFAs was much higher in the ascending-colon, this could be attributed to the higher $\mathrm{Na}^{+}, \mathrm{Cl}^{-}$, and water 
influx in this segment. In conclusion, marked segmental differences in the absorption of ranitidine $\mathrm{HCl}$ are apparent in the rabbit small and large intestine which could be significantly enhanced by the use of SCFAs.

\section{INTRODUCTION}

Short chain fatty acids, SCFAs are produced during fermentation of dietary fibers by colonic bacteria. Absorption of the SCFAs, acetate, propionate, and butyrate occurs primarily by nonionic diffusion and paracellular absorption in the proximal colon. ${ }^{1}$ However, an additional $\mathrm{SCFA}^{-} / \mathrm{HCO}_{3}^{-}$ exchange mechanism is present in the luminal membrane of rat colonic epithelial cells. ${ }^{2-4}$ Absorption of SCFAs not only serves as an additional energy supply for colonic epithelial cells, but it has also a significant impact on $\mathrm{NaCl}$ and water absorption. ${ }^{5-7}$ SCFAs stimulate electroneutral uptake of $\mathrm{Na}^{+}$, presumably by acidification of colonocytes and activation of apical $\mathrm{Na}^{+} / \mathrm{H}^{+}$exchangers. ${ }^{8} \mathrm{Cl}^{-}$absorption is stimulated by increased $\mathrm{HCO}_{3}^{-}$production during SCFAs metabolism. Another model is reported in which butyrate is taken up via nonionic diffusion or $\mathrm{SCFA}^{-} / \mathrm{HCO}_{3}^{-}$exchange. Subsequently electroneutral $\mathrm{NaCl}$ absorption is activated by parallel $\mathrm{Cl}^{-} /$butyrate and $\mathrm{Na}^{+} / \mathrm{H}^{+}$ exchange. ${ }^{9}$ Thus SCFAs transport is an important factor that regulates colonic fluid balance and absorption of $\mathrm{NaCl}$ and water from the intestine. The increased net water flux associated with absorption of SCFAs would enhance the absorption of polar compounds due to solvent drag effect via the paracellular pathway.The major objective of the present study was to examine the influence of increased chain length of short chain fatty acids (SCFAs) on the effective permeability surface area product normalized to the intestinal length $(\mathrm{PeA} / \mathrm{L})$, of the $\mathrm{H}_{2}$-receptor antagonist, ranitidine $\mathrm{HCl}$, using single pass intestinal perfusion technique, in situ, in the rabbit. ${ }^{10-12}$ Another important secondary objective of this study was to estimate the membrane transport parameters of ranitidine $\mathrm{HCl}$ in both the jejunoileum and ascending colon of the rabbit intestine and integrate such estimations with the net water flux to establish a baseline correlation between the solvent drag effect and intestinal absorption of this drug. Ranitidine $\mathrm{HCl}$ was selected as a model polar drug having relatively, low oral bioavailability. Ranitidine hydrochloride is a histamine $\mathrm{H}_{2}$-receptor antagonist. it occurs as a white to pale yellow granular substance having a slightly bitter taste and sulfur-like odor, the drug has a $\mathrm{pK}_{\mathrm{a}}$ of 2.7, and $\mathrm{pk}_{\mathrm{b}}$ of 8.2 , and solubilities of $660 \mathrm{mg} / \mathrm{mL}$ in water and $190 \mathrm{mg} / \mathrm{mL}$ in alcohol respectively, ${ }^{13,14}$ Ranitidine competitively inhibits the action of histamine on the $\mathrm{H}_{2}$ receptors of parietal cells, reducing gastric acid secretion under daytime and nocturnal basal conditions and also when stimulated by food, histamine, pentagastrin, ${ }^{13}$ insulin, and amino acids. ${ }^{15}$ Ranitidine $\mathrm{HCl}$ is $50 \%$ absorbed after oral administration, compared to an iv-injection with mean peak levels of 440 to $545 \mathrm{ng} / \mathrm{ml}$ occurring at 2 to 3 hours after a 150-mg dose. The plasma profile of healthy volunteers after oral or intravenous administration of the drug presents at least two peaks. ${ }^{16-18}$ Several authors considered the existence of secondary peaks as a result of discontinuous absorption from ${ }_{21}$ specific sites along the gastrointestinal tract. ${ }^{19-}$

\section{MATERIALS AND METHODS}

\section{A- Materials}

Ranitidine $\mathrm{HCl}$, caffeine, sodium acetate, sodium propionate, and sodium butyrate, were all purchased from Sigma chemical Co. (St.Louis, MO, USA). Monobasic ammonium phosphate and phosphoric acid were obtained from Merck, Darmstadt, Germany. Acetonitrile HPLC-grade was obtained from $\mathrm{BDH}$ Laboratory, England. Sodium chloride 0.9\% for injection, USP was obtained from El-Nasr Pharmaceutical Chemicals Company, Egypt. Ketamine $\mathrm{HCl}(100 \mathrm{mg} / \mathrm{ml})$ was obtained From EIPICO Pharmaceutical Company, Egypt. Chlorpromazine $\mathrm{HCl}(25 \mathrm{mg} / \mathrm{ml})$ was obtained From Misr Pharmaceutical Company, Egypt. All chemicals were of analytical reagent grade. 


\section{B- Equipment}

Peristaltic pump (LKB-Produkter AB S16125 Bromma, Sweden), Timer, pH meter (Digi-Sense $^{\circledR}$, Cole-Parmer Instrument Company, Niles, IL 60714, USA), Water bath $\left(\right.$ Gerhardt $^{\circledR}$, H. Jurgens \& Co.-GmbH \& Co.Bremen, Germany), Centrifuge (Minor 35, M.S.D., L.T.D., England). High pressure liquid chromatograph (Waters ${ }^{\mathrm{TM}} 600$ controller, USA) equipped with a variable wavelength detector (Waters ${ }^{\mathrm{TM}}$ 486, Tunable Absorbance Detector, USA) and an automatic sampling system (Waters $^{\mathrm{TM}} 717$ Plus Autosampler, USA) and the whole equipment is under computer control. Reversed phase column $15 \mathrm{~cm} \mathrm{X} 3.9$ $\mathrm{mm}$ (i.d.) $\mathrm{C}_{18}, \mu$ Bondapak $^{\mathrm{TM}}$, Waters, with an average particle size of $10 \mu \mathrm{m}$.

\section{C- Preparation of the drug solutions for intestinal perfusion}

The perfusion solutions containing 0.2 $\mathrm{mM}$ ranitidine $\mathrm{HCl}$ were prepared by simply weighing the exact amount of the drug and dissolving it in $0.9 \%$ sodium chloride for injection, USP. In the experiments that involved coperfusion of SCFA as an absorption enhancer, ranitidine $\mathrm{HCl}$ was dissolved in $0.9 \%$ sodium chloride for injection, USP containing $25 \mathrm{mM}$ of either sodium acetate, sodium propionate or sodium butyrate. All the solutions were freshly prepared on the day of the experiment and sonicated for 30 minutes to ensure complete dissolution of the drug and enhancer.

\section{D- Segment preparation}

Male albino rabbits weighing $2.8-3.1 \mathrm{~kg}$ were utilized in these experiments. Prior to surgery, the rabbit was fasted over night. The animal was then anesthetized by intramuscular injections of ketamine $\mathrm{HCl}$, given in two doses each of $45 \mathrm{mg} / \mathrm{kg}$ at 15 minutes interval and a third dose of $25 \mathrm{mg} / \mathrm{kgm}, 15$ minutes later. Chloropromazine $\mathrm{HCl}$ was used as muscle relaxant (two doses of $2 \mathrm{mg} / \mathrm{kgm}$ given i.m at $15 \mathrm{~min}$ interval). The injections were given rapidly and deeply into the thigh muscle.

After induction of anesthesia the rabbit was laid in a supine position on an underpad, which was placed over a heating pad to maintain body temperature throughout the experiment. The abdominal area was shaved and cleaned with a depilatory cream, a longitudinal incision 6-8 $\mathrm{cm}$ was made. The intestinal segments of interest were exposed and isolated carefully. In order to cannulate the jejunoileum segment, the proximal end was tied off using surgical silk, then it was cannulated using a 3-way stopcock cannula. The desired length of the intestinal segment was then measured by a premeasured thread, and the distal end was cannulated using an Lshaped glass cannula.

For the colon, the proximal end was tied off immediately after the ampulla coli, the desired length $(15 \mathrm{~cm})$ was measured adopting the same procedures, and finally the distal end tied off. Two incisions were made, one on each end, and the solid fecal debris was squeezed out by gentle manipulation of the segment. The rest of the fecal debris was forced out by gently infusing $37^{\circ}$ normal saline through the proximal end. Finally, both the proximal and distal ends were cannulated as described before. The isolated segment was kept warm and moist by frequent application of $37^{\circ}$ normal saline to a gauze pad covering the intestine. The remainder of the intestine was returned into the abdominal cavity for better maintenance of the temperature. The isolated segments were kept in a horizontal level throughout the experiment to avoid the hydrostatic pressure which could affect the fluid movement across the intestinal membrane. At the end of the experiment the animal was euthanized by injecting an overdose of sodium pentobarbital through the marginal ear vein. The intestinal segments under study were excised and an exact measure of the length of these segments was done by placing each segment on a ruler wetted with normal saline. This length was used for calculation of the membrane transport parameters of ranitidine $\mathrm{HCl}$.

\section{E- Experimental design}

Four groups, each consisted of three male, albino rabbits weighing 2.8-3.1 kg were used in these experiments. The first group was utilized to estimate the membrane transport parameters of ranitidine $\mathrm{HCl}$ in both the jejunoilum and ascending-colon of the rabbit intestine. The intestinal perfusion was conducted in both segments in the same time in order to allow for comparison between parameters under identical conditions. The other three groups were 
utilized to examine the effect of SCFAs (sodium acetate, sodium propionate, and sodium butyrate) on the absorptive clearance of ranitidine $\mathrm{HCl}$ from both segments. The drug concentration was $0.2 \mathrm{mM}$, while the concentration of each enhancer was $25 \mathrm{mM}$, which was coperfused alone with the drug $(\mathrm{n}=3)$.

\section{F- In Situ intestinal perfusion}

Solutions containing ranitidine $\mathrm{HCl}$ in normal saline, as described before were perfused at a flow rate of $0.37 \mathrm{ml} / \mathrm{min}$. The intestinal effluent samples were collected at 10minutes intervals for 120 minutes in $10-\mathrm{ml}$ preweighed stoppered tubes. These tubes were weighed again after sample collection, and the effluent weight was recorded as the difference. Intestinal net water flux was estimated gravimetrically and effluent concentrations were corrected accordingly.

\section{G- Chromatography Standard solutions}

A 7-point standard curve was prepared by adding appropriate volumes of ranitidine $\mathrm{HCl}$ stock solution in methanol into a series of 13$\mathrm{ml}$ ground glass stoppered centrifuge tubes in the amount of $0.1,0.5,1,5,10,20$, and $50 \mu \mathrm{g}$. Each of these tubes was spiked with $7.0 \mu \mathrm{g}$ of caffeine as an internal standard. The methanol was evaporated off and the residue was reconstituted in one $\mathrm{ml}$ of mobile phase, vortex-mixed, and $200 \mu \mathrm{l}$ were transferred to microvials which were loaded on automatic sampler after crimping for injection.

\section{Samples}

The perfusate samples collected during the intestinal perfusion were centrifuged for 5 minutes in order to precipitate any mucus debris. $200 \mu$ of the supernatant as well as the solutions remaining after intestinal perfusion were withdrawn and added to test tubes spiked with $7.0 \mu \mathrm{g}$ internal standard, caffeine. Another $800 \mu \mathrm{l}$ of the mobile phase was added and the tubes were vortexed for 1 minute. $200 \mu \mathrm{l}$ were then transferred to microvials which were loaded on the automatic sampler after crimping to avoid evaporation of the solvent. $40 \mu \mathrm{L}$ of these samples together with standards were injected. Isocratic separation was achieved using a $15 \mathrm{~cm} \quad X \quad 3.9 \mathrm{~mm}$ (i.d.) $\mathrm{C}_{18}, \mu$
Bondapak $^{\mathrm{TM}}$, Waters, reversed phase column with an average particle size of $10 \mu \mathrm{m}$ and a mobile phase consisted of $10 \mathrm{mM}$ monobasic ammonium phosphate dissolved in wateracetonitrile (90:10). The $\mathrm{pH}$ was adjusted to 6.0 by addition of phosphoric acid. The flow rate was $1.2 \mathrm{ml} / \mathrm{min}$ and the temperature was ambient. The effluent samples were detected at $228 \mathrm{~nm}$. Under these conditions the retention time of the drug and internal standard was 2.51 and 4.95 minutes, respectively. Figure 1 shows a typical chromatogram obtained during the analysis of perfusate samples containing ranitidine $\mathrm{HCl}$. Analysis of the solutions remaining after intestinal perfusion was done in order to determine the inflow concentration accurately. The peak areas for ranitidine $\mathrm{HCl}$ and caffeine were calculated with the millennium $^{32}$ software. The calibration curves were constructed from the drug concentrations and peak area ratios of the drug/internal standard. The peak area ratios for the unknown samples were used to calculate the unknown concentrations from the standard calibration curves.

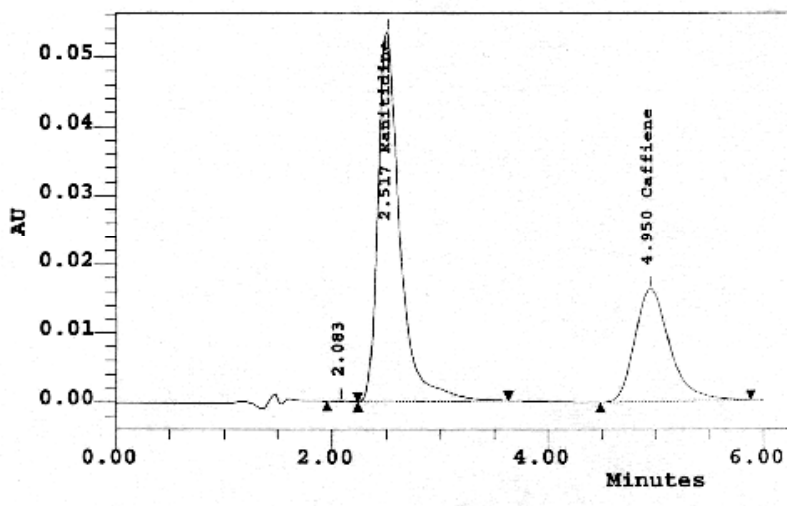

Fig. 1: Typical chromatogram obtained during the analysis of perfusate samples containing ranitidine $\mathrm{HCl}$. The retention time for ranitidine and caffeine (IS) was 2.51 , and 4.95 minutes, respectively.

\section{H- Data analysis}

\section{Absorptive clearance}

The flow rate was estimated for each perfusion experiment from the linear regression of the volume remaining during perfusion versus time. The volume of the outflow samples was estimated gravimetrically taking the density of the aqueous samples as 1.0, the same as water. From the difference in flow rate 
entering and leaving the intestinal segment, the outflow concentration was corrected for net water flux. The ratio between the corrected concentration at the outflow $\left(\mathrm{C}_{1}\right)$ and that at the inflow $\left(\mathrm{C}_{0}\right)$ was calculated for each perfusate sample collected. The average of the outflowto-inflow concentration ratios for the fractions collected from 70 to 120 min was taken as the steady-state ratio. This ratio at steady-state is given by: ${ }^{22-24}$

$\left\{\frac{\mathrm{C}_{1}}{\mathrm{C}_{0}}\right\}_{\mathrm{ss}}=\exp ^{-\left(\frac{\text { Pe.A }}{\mathrm{Q}}\right)}$

where $\mathrm{C}_{1}$ is the corrected concentration leaving the intestinal segment, $\mathrm{C}_{\mathrm{O}}$ is the concentration entering the segment, $\left\{\mathrm{C}_{1} / \mathrm{C}_{0}\right\}_{\mathrm{ss}}$ is the fraction remaining to be absorbed at steady-state, $\mathrm{A}$ is the effective surface area $\left(\mathrm{cm}^{2}\right), \mathrm{Pe}$ is the apparent permeability coefficient $(\mathrm{cm} / \mathrm{min})$, and $\mathrm{Q}$ is the bulk perfusate flow rate $(\mathrm{mL} / \mathrm{min})$ within the intestinal segment.

Rearrangement of Equation (1) allows the permeability-area product ( $\mathrm{Pe} * \mathrm{~A})$ to be calculated. The $\left(\mathrm{Pe}^{*} \mathrm{~A}\right)$ could be considered to be the absorptive clearance $(\mathrm{mL} / \mathrm{min})$ :

$\mathrm{PeA}=-\mathrm{Q} \ln \left(\frac{\mathrm{C}_{1}}{\mathrm{C}_{0}}\right)_{\mathrm{ss}}$

After correction for the net water flux:

$\mathrm{PeA}=-\mathrm{Q}^{*} \ln \left\{\frac{\left(\mathrm{C}_{\text {(out) }} * \mathrm{Q}_{\text {(out) }}\right)}{\left(\mathrm{C}_{\text {(in) }} * \mathrm{Q}_{\text {(in) }}\right)}\right\}_{\mathrm{ss}}$

where $\mathrm{Q}_{\text {(in) }}$ is the flow rate entering the intestinal segment and $\mathrm{Q}_{\text {(out) }}$ is the flow rate leaving it. Since $\left\{\left(\mathrm{C}_{\text {(out) } *} \mathbf{Q}_{\text {(out })}\right) /\left(\mathrm{C}_{\text {(in) }} * \mathrm{Q}_{\text {(in) }}\right)\right\}_{\text {ss }}$ is the fraction remaining after solution has passed through the intestinal length (1), then the fraction absorbed is:

$\mathrm{Fa}=1-\left\{\frac{\left(\mathrm{C}_{\text {(out) }} * \mathrm{Q}_{\text {(out) }}\right)}{\left(\mathrm{C}_{\text {(in) }} * \mathrm{Q}_{\text {(in) }}\right)}\right\}_{\mathrm{ss}}=1-\exp ^{-(\mathrm{PeA} / \mathrm{Q})}$

The anatomical reserve length (ARL) was given by: ${ }^{24}$

$\mathrm{ARL}=\left(\mathrm{L}^{*}\right)-\left(1^{*}\right)$

where, ARL is defined as the length, $(\mathrm{cm})$ of the intestine remaining after absorption has been completed for a given solute. $\mathrm{L}^{*}$ is the maximal intestinal length available for absorption. $1^{*}$ is the intestinal length along which absorption is complete, (cm). An arbitrary small fraction of solute remaining in the lumen was considered as the criteria for complete absorption. ${ }^{24}$ Taking this fraction as $5 \%$, and replacing in equation (1) will give the following equation:

$0.05=\exp ^{-\left\{\left(\text {PeA. } .^{*}\right) / \mathrm{Q}\right\}}$

where, PeA is the effective permeability surface area product normalized to length. $1^{*}$ is the length required for 95\% absorption (L95\% ab.) of a given solute.

\section{Effect of solvent drag on intestinal absorptive clearance}

The influence of water flux on the absorption of the drugs across the intestinal membrane was studied by plotting the absorptive clearance versus the net water flux $\mathbf{J}_{\mathrm{w}}$, where $\mathbf{J}_{\mathrm{w}}(\mathrm{ml} / \mathrm{min})$ is given by:

$\mathrm{J}_{\mathrm{w}}=\mathrm{Q}_{\text {in }}-\mathrm{Q}_{\text {out }}$

The net amount of drug absorbed per unit time can be described as the sum of two terms, the diffusive contribution and the convective contribution corresponding to the solvent drag effect. The net amount of drug absorbed per unit time is then given by: ${ }^{25-27}$

$\mathrm{J}_{\mathrm{s}}=\mathrm{K}_{\mathrm{s}}\left(\mathrm{C}-\mathrm{C}_{\mathrm{p}}\right)+\Phi_{\mathrm{s}} \mathrm{J}_{\mathrm{w}} \mathrm{C}$

In which, the first term on the right is diffusive and the second is convective and, $\mathrm{J}_{\mathrm{s}}$, is the rate of absorption of the solute from the lumen $(\mu \mathrm{g} / \mathrm{min})$. Ks is the diffusive permeability coefficient given by $\mathrm{DAK}_{\mathrm{p}} / \mathrm{x}$. In which $\mathrm{D}$, is the diffusion coefficient of the solute, $A$, is the effective surface area, $K_{p}$, is the partition coefficient of the solute, and $\mathrm{x}$, is the path length. $\mathrm{C}, \mathrm{C}_{\mathrm{p}}$ are the solute concentrations in the lumen and plasma, respectively. $\Phi_{s}$, is the sieving coefficient of the given compound, represents the ratio between the concentration of the compound in the convective stream to that in the luminal fluid. $J_{w}$, is the rate of water flux within the intestinal segment. At the steady state, due to sink conditions in the blood, equation (8) is reduced to: 
$\mathrm{J}_{\mathrm{ss}}=\frac{\mathrm{DAK}_{\mathrm{p}}}{\Delta \mathrm{X}}\left(\mathrm{C}_{\mathrm{ss}}\right)+\Phi \mathrm{J}_{\mathrm{w}}\left(\mathrm{C}_{\mathrm{ss}}\right)$

where, $\mathrm{J}_{\mathrm{ss}}$ is the steady state solute flux $(\mu \mathrm{g} / \mathrm{min})$ and $\mathrm{C}_{\mathrm{ss}}$ is the length averaged steady state concentration of the solute in the lumen $(\mu \mathrm{g} / \mathrm{ml})$. Rearrangement of equation (9) gives:

$$
\frac{\mathrm{J}_{\mathrm{ss}}}{\mathrm{C}_{\mathrm{ss}}}=\frac{\mathrm{DAK}_{\mathrm{p}}}{\Delta \mathrm{X}}+\Phi \mathrm{J}_{\mathrm{w}}
$$

The term $\mathrm{J}_{\mathrm{ss}} / \mathrm{C}_{\mathrm{ss}}$ represents the overall absorptive clearance of the given solute $(\mathrm{ml} / \mathrm{min})$, regardless its route or mechanism.

\section{Statistical analysis}

The membrane transport parameters of ranitidine $\mathrm{HCl}$ were determined in both the jejunoileum and ascending-colon of the rabbit intestine when ranitidine $\mathrm{HCl}$ was perfused alone or in presence of the SCFAs as absorption enhancers. The Student's t-test was utilized to compare between pharmacokinetic parameters obtained in both segments when ranitidine $\mathrm{HCl}$ was perfused alone or in combination with the SCFAs in order to determine if coadministration of the SCFAs improve the intestinal absorption of ranitidine $\mathrm{HCl}$ in the rabbit. P-value $<0.05$ was considered significant.

\section{RESULTS AND DISCUSSION}

\section{Segmental differences in the absorption of ranitidine $\mathrm{HCl}$ from rabbit intestine}

Ranitidine $\mathrm{HCl}$ was incompletey absorbed from the rabbit small and large intestine. The membrane transport parameters of this compound were estimated and summarized in Table 1. The length required for complete absorption of this compound (L 95\%) reaches $(396 \pm 51 \mathrm{~cm})$ in the jejunoileum and $(234 \pm 6$ $\mathrm{cm})$ in the ascending colon, this means that complete absorption of this compound occurs hypothetically beyond the whole length of the intestine in both regions and the absorption of this compound is incomplete from the small and large intestine. These results are consistent with previous oral bioavailability studies of ranitidine $\mathrm{HCl}$ in humans which indicated that the oral bioavailability of this compound is incomplete. $^{18,28}$ The absorptive clearance normalized for the intestinal length $(\mathrm{PeA} / \mathrm{L}$, $\mathrm{ml} / \mathrm{min} \mathrm{cm}$ ) indicated that the absorption of ranitidine $\mathrm{HCl}$ is higher in the ascending colon compared with the jejunoileum. The $\mathrm{PeA} / \mathrm{L}$ value in the ascending colon was $(0.0058 \pm$ $0.0002)$, which is almost double that in the jejunoileum $(0.0028 \pm 0.0004) \mathrm{ml} / \mathrm{min} \mathrm{cm}(\mathrm{P}$ value $<0.05)$. This was reflected as double amount absorbed per unit length in the ascending-colon compared with the jejunoileum, where the percentage fraction absorbed per unit length $(\% \mathrm{Fa} / \mathrm{cm})$ was $(1.63 \pm 0.07)$ in the ascending-colon compared with $(0.75 \pm 0.07)$ in the jejunoileum. The delayed absorption of ranitidine $\mathrm{HCl}$ from the ascending colon may account for the presence of a secondary peak in the plasma profile of healthy volunteers after oral administration of the drug. ${ }^{16-18}$ Several authors considered the existence of secondary peaks as a result of discontinuous absorption from specific sites along the gastrointestinal tract. ${ }^{19-21}$ Sitedependent small intestinal absorption of ranitidine in healthy, male volunteers was repoted. ${ }^{19}$ The absorption rates calculated from intestinal samples showed distinct sitedependence, the highest rates were found in the most proximal region (duodenojejunal junction), and the most distal perfusion sites (distal ileum). In both of these regions there was a significant positive correlation between the net intestinal water flux and the movement of ranitidine. Within the mid-jejunum, every subject showed marked secretion of ranitidine into the gut lumen, and in this region there was no influence of water flux on ranitidine movement. The intraluminal results were confirmed by the corresponding site-dependent areas under the serum concentration-time curves (AUC), which decreased with the distance of the perfusion site from the teeth. The results demonstrated that the small intestine is a site of a gradient of absorption of ranitidine. In another study that was conducted on rats, ${ }^{29}$ the results showed that ranitidine absorption from the lower ileum contributes significantly to systemic ranitidine concentrations before and during the time of the first concentration maximum. Separation of the drug mass into multiple boluses may contribute to secondary peaks in ranitidine concentration-time profiles. 
Table 1: Membrane transport parameters of ranitidine $\mathrm{Hcl}$ from the rabbit small and large intestine.

\begin{tabular}{|c|c|c|c|c|c|c|}
\hline \multicolumn{7}{|c|}{ Jejunoileum } \\
\hline $\begin{array}{l}\text { Rabbit } \\
\text { Iden. }\end{array}$ & $\begin{array}{c}\mathrm{PeA} / \mathrm{L} \\
\mathrm{ml} / \mathrm{min} . \mathrm{cm}\end{array}$ & $\mathrm{R}$ (out)/R(in) & $\% \mathrm{Fa}$ & $\% \mathrm{Fa} / \mathrm{cm}$ & $\begin{array}{c}\mathrm{PeA} \\
\mathrm{ml} / \mathrm{min}\end{array}$ & $\begin{array}{c}\mathrm{L}(95 \% \mathrm{ab}) \\
\mathrm{cm}\end{array}$ \\
\hline $\mathrm{R} 1$ & 0.0035 & 0.6662 & 33.38 & 0.88 & 0.1076 & 300.16 \\
\hline R7 & 0.0023 & 0.8071 & 19.29 & 0.62 & 0.0707 & 474.82 \\
\hline $\mathrm{R} 8$ & 0.0026 & 0.7844 & 21.56 & 0.74 & 0.0796 & 415.61 \\
\hline mean & 0.0028 & 0.7526 & 24.74 & 0.75 & 0.0860 & 396.86 \\
\hline$\pm \mathrm{SE}$ & 0.0004 & 0.0437 & 4.37 & 0.07 & 0.0111 & 51.28 \\
\hline \multicolumn{7}{|c|}{ Ascending colon } \\
\hline $\begin{array}{l}\text { Rabbit } \\
\text { Iden. }\end{array}$ & $\begin{array}{c}\mathrm{PeA} / \mathrm{L} \\
\mathrm{ml} / \mathrm{min} . \mathrm{cm}\end{array}$ & $\mathrm{R}$ (out)/R(in) & $\% \mathrm{Fa}$ & $\% \mathrm{Fa} / \mathrm{cm}$ & $\begin{array}{c}\mathrm{PeA} \\
\mathrm{ml} / \mathrm{min}\end{array}$ & $\begin{array}{c}\mathrm{L}(95 \% \mathrm{ab}) \\
\mathrm{cm}\end{array}$ \\
\hline $\mathrm{R} 1$ & 0.0062 & 0.8689 & 13.11 & 1.64 & 0.0496 & 221.76 \\
\hline R7 & 0.0054 & 0.8355 & 16.45 & 1.50 & 0.0595 & 238.81 \\
\hline $\mathrm{R} 8$ & 0.0058 & 0.8259 & 17.41 & 1.74 & 0.0642 & 241.70 \\
\hline mean & $0.0058^{*}$ & 0.8434 & 15.66 & 1.63 & 0.0578 & 234.09 \\
\hline$\pm \mathrm{SE}$ & 0.0002 & 0.0130 & 1.30 & 0.07 & 0.0043 & 6.22 \\
\hline
\end{tabular}

Statistically different from jejunoileum, P-value $<0.05$.

Contribution of the solvent drag to the absorptive clearance of ranitidine $\mathrm{HCl}$ from rabbit small and large intestine

Ranitidine $\mathrm{HCl}$ is relatively polar compound with a solubility of $660 \mathrm{mg} / \mathrm{ml}$ in water. ${ }^{13}$ The solvent drag appears to influence its absorptive clearance to a major extent through the paracellular route. Figure 2, indicates that the absorptive clearance $(\mathrm{PeA} / \mathrm{L}$, $\mathrm{ml} / \mathrm{min} \mathrm{cm})$ ) of this compound increased linearly as a result of increasing net water flux $(\mathrm{JW} / \mathrm{L}, \mathrm{ml} / \mathrm{min} \mathrm{cm})$, this effect was more pronounced in the ascending colon compared with the jejunoileum due to the higher water flux in this segment. According to Lifson's model ${ }^{25,} 26$ equation (10) represents the transcellular and paracellular contributions to the overall absorptive clearance of a given compound. Fitting the linear regression equations obtained in Figure 2 to this model demonstrated clearly that the drug is dependent entirely on the convective component through the paracellular route in its absorption. The transcellular diffusive component of this compound is zero as indicated from the negative intercept in the jejunoileum and ascending colon (the intercept is statistically not different from zero). The importance of solvent drag on the absorption of numerous drugs through the paracellular pathway had been well established. ${ }^{30-33}$ The relative contributions of the diffusive (DKA/ $\mathrm{x}$ ) and convective $(\Phi \mathrm{Jw})$ clearances to the overall absorptive clearance (Eq. 10) were estimated from the linear regression equation obtained in Figure 2. The average of the overall absorptive clearance (DKA/ $\mathrm{x}+\Phi \mathrm{Jw}$ ) in the jejunoileum is $(0.0028 \pm 0.0004)$, while that in the ascending colon is $(0.0058 \pm 0.0002) \mathrm{ml} / \mathrm{min}$ $\mathrm{cm}$, the intercept obtained from the linear regression equation (Figure 2) is considered to be zero (Statistically not different from zero), which represents the transport via the transcellular pathway (DKA/ $\mathrm{x}$ ). This means that $100 \%$ of the absorptive clearance is represented by the paracellular convective component $(\Phi \mathrm{Jw})$. 


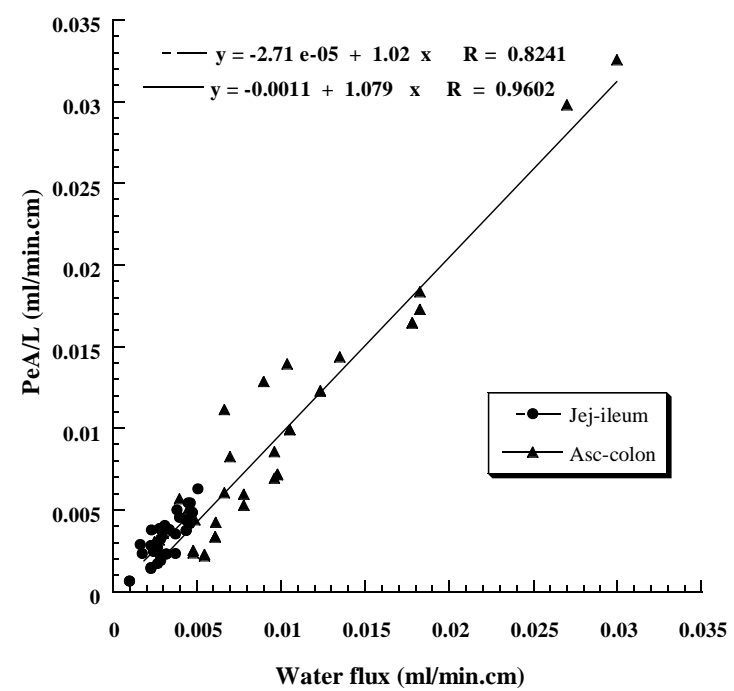

Fig. 2: Effect of net water flux on the absorptive clearance of ranitidine $\mathrm{HCl}$ from the jejunoileum and ascending-colon of rabbit intenstine $(n=3)$.

The sieving coefficient of ranitidine $\mathrm{HCl}$ $(\Phi)$ obtained from the linear regression equation (Figure 2), is almost 1.0 in both the jejunoileum and ascending colon indicating a high extent of interaction with water for this compound. Since one of the major physiological functions of the ascending colon is the absorption of water and sodium, ${ }^{34}$ thus the entrainment of ranitidine $\mathrm{HCl}$ in the stream of influxed water represents the major transport mechanism in this segment through the paracellular pathway, this was reflected as higher correlation value in the ascending colon compared with the jejunoileum $(\mathrm{R}=0.96$ in ascending colon versus 0.82 in the jejunoileum, Figure 2). On the other hand the anatomic radius of the colonic segment is higher compared with the jejunoileum, applying the same volumetric flow rate $(0.37 \mathrm{ml} / \mathrm{min})$ in both segments during perfusion results in a slower linear flow velocity $(\beta)$ in the ascending colon compared with the jejunoileum. Since the linear flow velocity $(\beta)$ is correlated with the volumetric flow velocity $(\mathrm{Q})$ by the formula: ${ }^{35}$

$\beta=\mathrm{Q} / \pi \mathrm{r}^{2} \quad \mathrm{~cm} / \mathrm{min}$

Thus the mean residence time in the ascending colon is higher compared with the jejunoileum, which allows for higher value of the absorptive clearance, $(\mathrm{PeA} / \mathrm{L})$ in this segment which is almost double that in the jejunoileum, $(0.0058 \pm 0.0002)$ versus $(0.0028$ $\pm 0.0004) \mathrm{ml} / \mathrm{min} \mathrm{cm}$. (P-value < 0.05). In a study conducted on Caco-2 cell monolayers, ${ }^{36}$ the apparent permeability coefficient $\left(\mathrm{P}_{\mathrm{app}}\right)$ value for ranitidine was increased by $15-$ to 20 fold in a calcium-free medium or in the transport medium containing EDTA, indicating that the paracellular passive diffusion is the rate determining pathway for the transport of ranitidine. The apparent permeability coefficients $\left(\mathrm{P}_{\text {app }}\right)$ were unchanged throughout the concentration range studied, indicating a passive diffusion pathway across intestinal mucosa. In another study conducted on rats ${ }^{37}$ the uptake rate of ranitidine from the jejunum and colon was linear with a concentration range of $0.0005-5 \mathrm{mM}$, and there was no competition for uptake by either famotidine or cimetidine. The results indicated that uptake of ranitidine in the rat jejunum and colon occurs by a predominantly passive process and ranitidine exhibited regional differences in uptake rate in both segments.

\section{Effect of short chain fatty acids (SCFAs) on membrane transport parameters of ranitidine $\mathrm{HCl}$ from rabbit intestine}

The effect of coperfusion of SCFAs on the membrane transport parameters of ranitidine $\mathrm{HCl}$ from the jejunoileum and ascending colon of the rabbit intestine is depicted in Tables 2 and 3, respectively. All the three compounds had increased the absorptive clearance $(\mathrm{PeA} / \mathrm{L})$ of ranitidine $\mathrm{HCl}$ from both segments, however the effect of both sodium butyrate and sodium propionate was statistically different from the control (P-value $<0.05$ ), while that of sodium acetate was statistically insignificant ( $\mathrm{P}$-value $>0.05$ ). Sodium butyrate exerted the highest enhancing effect on both the absorptive clearance normalized to the intestinal length $(\mathrm{PeA} / \mathrm{L})$ and the percentage fraction absorbed per unit length $(\% \mathrm{Fa} / \mathrm{cm})$ of ranitidine $\mathrm{HCl}$. The values of these parameters were almost double compared with the control in both the anatomical sites studied (Tables 2 and 3). Sodium propionate had a significant enhancing effect on both parameters in both segments studied compared with the control (P-value < 0.05), however there was no statistical difference between the effect of butyrate and propionate. Sodium acetate had also 
Table 2: The Effect of SCFAs Coperfusion on Membrane Transport Parameters of Ranitidine $\mathrm{HCl}$ in the jejunoileum of the Rabbit intestine.

\begin{tabular}{|c|c|c|c|c|}
\hline Parameter & $\begin{array}{c}\text { Control } \\
\text { Mean } \\
( \pm \text { SD, n=3) } \\
\end{array}$ & $\begin{array}{c}\text { Acetate* }^{*} \\
\text { Mean } \\
( \pm \text { SD, } n=3) \\
\end{array}$ & $\begin{array}{c}\text { Propionate* } \\
\text { Mean } \\
( \pm \mathrm{SD}, \mathrm{n}=3)\end{array}$ & $\begin{array}{c}\text { Butyrate* } \\
\text { Mean } \\
( \pm \text { SD, } n=3) \\
\end{array}$ \\
\hline $\begin{array}{c}\text { Absorptive } \\
\text { clearance, } \mathrm{PeA} / \mathrm{L} \\
(\mathrm{ml} / \mathrm{min} . \mathrm{cm})\end{array}$ & $\begin{array}{c}0.0028 \\
(0.0004)\end{array}$ & $\begin{array}{c}0.0038 * * \\
(0.0004)\end{array}$ & $\begin{array}{c}0.0042 * * * \\
(0.0002)\end{array}$ & $\begin{array}{c}0.0060 * * * \\
(0.0011)\end{array}$ \\
\hline $\begin{array}{c}\text { Fraction remaining } \\
\text { to be absorbed } \\
\mathrm{R} \text { (out)/R(in) } \\
\end{array}$ & $\begin{array}{c}0.7526 \\
(0.0437)\end{array}$ & $\begin{array}{c}0.7425 \\
(0.0387)\end{array}$ & $\begin{array}{c}0.6353 \\
(0.0131)\end{array}$ & $\begin{array}{c}0.4955 \\
(0.0405)\end{array}$ \\
\hline $\begin{array}{c}\text { \% Fraction absorbed } \\
(\% \mathrm{Fa})\end{array}$ & $\begin{array}{l}24.74 \\
(4.37) \\
\end{array}$ & $\begin{array}{l}25.78 \\
(3.87) \\
\end{array}$ & $\begin{array}{l}36.47 \\
(1.31) \\
\end{array}$ & $\begin{array}{l}50.45 \\
(4.05) \\
\end{array}$ \\
\hline $\begin{array}{c}\% \text { Fraction absorbed } \\
\text { normalized to length } \\
(\% \mathrm{Fa} / \mathrm{cm})\end{array}$ & $\begin{array}{c}0.75 \\
(0.07)\end{array}$ & $\begin{array}{c}0.9567 \\
(0.0915)\end{array}$ & $\begin{array}{c}1.06 \\
(0.0089)\end{array}$ & $\begin{array}{c}1.39 \\
(0.2246)\end{array}$ \\
\hline $\begin{array}{l}\text { Length required for } \\
\text { complete absorption } \\
(\mathrm{L} 95 \%),(\mathrm{cm})\end{array}$ & $\begin{array}{l}396.86 \\
(51.28)\end{array}$ & $\begin{array}{l}295.31 \\
(29.14)\end{array}$ & $\begin{array}{l}234.65 \\
(12.46)\end{array}$ & $\begin{array}{l}176.73 \\
(39.83)\end{array}$ \\
\hline $\begin{array}{l}\text { Anatomical reserve } \\
\text { length }(\mathrm{ARL}),(\mathrm{cm})\end{array}$ & $\begin{array}{l}-246.86 \\
(51.28)\end{array}$ & $\begin{array}{l}-145.31 \\
(29.14)\end{array}$ & $\begin{array}{l}-84.66 \\
(12.46)\end{array}$ & $\begin{array}{l}-26.73 \\
(39.83)\end{array}$ \\
\hline
\end{tabular}

* Sodium salt at $25 \mathrm{mM}$ concentration.

** Statistically not different from control P-value $>0.05$.

*** Statistically different from control P-value $<0.05$.

Table 3: The effect of SCFAs coperfusion on membrane transport parameters of ranitidine $\mathrm{HCl}$ in the ascending-colon of the rabbit intestine.

\begin{tabular}{|c|c|c|c|c||}
\hline Parameter & $\begin{array}{c}\text { Control } \\
\text { Mean } \\
( \pm \mathrm{SD}, \mathrm{n}=3)\end{array}$ & $\begin{array}{c}+ \text { Acetate* } \\
\text { Mean } \\
( \pm \mathrm{SD}, \mathrm{n}=3)\end{array}$ & $\begin{array}{c}+ \text { Propionate* } \\
\text { Mean } \\
( \pm \mathrm{SD}, \mathrm{n}=3)\end{array}$ & $\begin{array}{c}+ \text { Butyrate* } \\
\text { Mean } \\
( \pm \mathrm{SD}, \mathrm{n}=3)\end{array}$ \\
\hline $\begin{array}{c}\text { Absorptive clearance, } \\
\text { PeA/L (ml/min.cm) }\end{array}$ & $\begin{array}{c}0.0058 \\
(0.0002)\end{array}$ & $\begin{array}{c}0.0083^{* *} \\
(0.0009)\end{array}$ & $\begin{array}{c}0.0111^{* * *} \\
(0.0017)\end{array}$ & $\begin{array}{c}0.0128^{* * *} \\
(0.0003)\end{array}$ \\
\hline $\begin{array}{c}\text { Fraction remaining to } \\
\text { be absorbed, }\end{array}$ & $\begin{array}{c}0.8434 \\
\mathrm{R}(\text { out } / \mathrm{R}(\mathrm{in})\end{array}$ & $\begin{array}{c}0.7221 \\
(0.0130)\end{array}$ & $\begin{array}{c}0.6755 \\
(0.0147)\end{array}$ & $\begin{array}{c}0.5945 \\
(0.0282)\end{array}$ \\
\hline $\begin{array}{c}\text { \% Fraction absorbed } \\
(\% \mathrm{Fa})\end{array}$ & $\begin{array}{c}15.66 \\
(1.30)\end{array}$ & $\begin{array}{c}27.79 \\
(1.47)\end{array}$ & $\begin{array}{c}32.45 \\
(0.7370)\end{array}$ & $\begin{array}{c}40.55 \\
(2.82)\end{array}$ \\
\hline $\begin{array}{c}\text { \% Fraction absorbed } \\
\text { normalized to length } \\
(\% \mathrm{Fa} / \mathrm{cm})\end{array}$ & 1.63 & 2.28 & $\begin{array}{c}2.76 \\
(0.7175)\end{array}$ & $\begin{array}{c}3.04 \\
(0.15)\end{array}$ \\
\hline $\begin{array}{c}\text { Length required for } \\
\text { complete absorption } \\
(\mathrm{L} 95 \%)\end{array}$ & $\begin{array}{c}234.09 \\
(6.22)\end{array}$ & $\begin{array}{c}136.43 \\
(25.27)\end{array}$ & $\begin{array}{c}93.35 \\
(12.22)\end{array}$ & $\begin{array}{c}72.10 \\
(2.14)\end{array}$ \\
\hline $\begin{array}{c}\text { Anatomical reserve } \\
\text { length (ARL) (cm) }\end{array}$ & $\begin{array}{c}-214.09 \\
(6.22)\end{array}$ & $\begin{array}{c}-116.43 \\
(25.27)\end{array}$ & $\begin{array}{c}-73.35 \\
(12.22)\end{array}$ & $\begin{array}{c}-52.10 \\
(2.14)\end{array}$ \\
\hline
\end{tabular}

* Sodium salt at $25 \mathrm{mM}$ concentration.

** Statistically not different from control P-value $>0.05$.

$* * *$ Statistically different from control P-value $<0.05$. 
permeation enhancing action on ranitidine $\mathrm{HCl}$ but it was statistically insignificant compared with the control. So, the enhancing action of SCFAs on the membrane transport parameters of ranitidine $\mathrm{HCl}$ was in the order of butyrate > propionate $>$ acetate. In order to investigate this enhancing effect on the transport of ranitidine $\mathrm{HCl}$ we examined the effect of increased chain length of SCFAs on the net water flux in both segments. Figure 3 shows that the increase in the chain length of SCFAs is associated with an increase in the net water flux in both segments, especially in the ascending colon, this is because of higher water and sodium ions flux in this segment. ${ }^{34}$ Since the major transport mechanism of ranitidine $\mathrm{HCl}$ across the intestinal membrane is the passive diffusion via the paracellular convective pathway as we discussed previously, thus increasing the net water flux by coperfusion of SCFAs had resulted in a significant increase in the absorptive clearance of ranitidine $\mathrm{HCl}$, and all membrane transport parameters from rabbit small and large intestine. This effect was proportional to the chain length of SCFAs. The effect of butyrate on the paracellular permeability was studied on rat distal colonic epithelium using Ussing chambers. ${ }^{38}$ The results proved that the exposure to butyrate increased paracellular permeability in rat distal colon. The mechanism involved was related to the loss of differentiated surface epithelial cells, or as a physiological response to $\mathrm{Na}^{+}-$ coupled butyrate uptake. In another study conducted on rat and rabbit distal colon, ${ }^{39}$ butyrate significantly decreased conductance, decreased flux of sodium from serosa to mucosa, particularly in rabbit distal colon. Net $\mathrm{Cl}^{-}$secretion, induced by cholera toxins, was completely inhibited by butyrate. The effects of SCFAs on fluid and electrolyte absorption during cholera toxin (CT) -induced colonic secretion in rabbit was studied ${ }^{40}$ using a steadystate perfusion technique. Perfusion with SCFAs significantly $(\mathrm{P}<0.01)$ reduced colonic water secretion. Butyrate reduced water secretion the most (95\%), followed by propionate $(90 \%)$, and acetate $(80 \%)$. These results are consistent with our results which proved that the enhancing effect of SCFAs on net water absorption in the rabbit colon was in the order: butyrate $>$ propionate $>$ acetate.

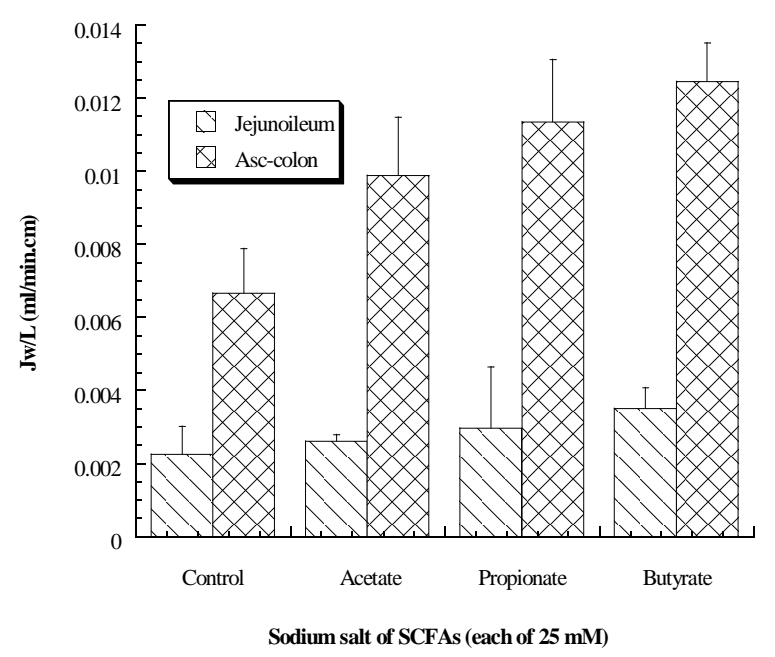

Fig. 3: Effect of SCFAs on the net water flux in the jejunoileum and ascending colon of rabit intestine (Mean $+S D),(n=3)$.

\section{Conclusion}

The study demonstrated that short chain fatty acids SCFAs, acetate, propionate, and butyrate had a significant effect on increasing the absorptive clearance normalized to the intestinal length $(\mathrm{PeA} / \mathrm{L})$ of ranitidine $\mathrm{HCl}$ in both the jejunoileum and ascending colon of the rabbit intestine. This effect was in the order butyrate > propionate > acetate, however there was no statistical difference between the effect of butyrate and propionate. The permeability enhancing effect of SCFAs was much higher in the ascending-colon, this could be attributed to the higher $\mathrm{Na}^{+}, \mathrm{Cl}^{-}$, and water influx in this segment. Marked segmental differences in the absorption of ranitidine $\mathrm{HCl}$ were found in the rabbit small and large intestine, the absorptive clearance $(\mathrm{PeA} / \mathrm{L})$ of this compound in the ascending colon was almost double that in the jejunoileum. Solvent drag had a significant effect on absorptive clearance (PeA/L) of ranitidine $\mathrm{HCl}$ which is transported across the intestinal membrane by passive diffusion via the paracellular pathway. 


\section{REFERENCES}

1- L. Luciano, E. Reale, G. Rechkemmer and W. Von Engelhardt, J. Membr. Biol., 82, 145-156 (1984).

2- A. N. Charney, L. Micic and R. W. Egnor, Am. J. Physiol Gastrointest Liver Physiol., 274, G518-G524 (1998).

3- N. Mascolo, V. M. Rajendran and H. J. Binder, Gastroenterology, 101, 331-338 (1991).

4- J. H. Sellin, R. De Soignie and S. Burlingame, J. Membr. Biol., 136, 147158 (1993).

5- R. A. Argenzio and S. C. Whipp, J. Physiol. (Lond.), 295, 365-381 (1979).

6- H. J. Binder and P. Mehta, Gastroenterology, 96, 989-996 (1989).

7- P. C. Dagher, R. W. Egnor, A. TagliettaKohlbrecher and A. N. Charney, Am. J. Physiol Cell Physiol., 271, C1853-C1860 (1996).

8- J. H. Sellin, and R. De Soignie, Gastroenterology, 114, 737-747 (1998).

9- V. M. Rajendran and H. J. Binder, J. Membr. Biol., 141, 51-58 (1994).

10- M. A. Osman, "In situ Absorption of Selected Antiviral Nucleosides from the Intestine of Experimental Animals", Ph.D. Thesis, Faculty of Pharmacy, University of Tanta, Tanta, Egypt (1995).

11- M. A. Osman, M. K. Youssef and R. J. Sawchuk, "In situ Absorption of the Antiviral Nucleoside Stavudine (D4T) from Rabbit Intestine", Poster Presentation at Alexandria $2^{\text {nd }}$ International Conference of Pharmaceutical Sciences and Technology, Alexandria, Egypt. October, 2000, Abstract book p. 56.

12- G. Gan, L. L. Cartier, Y.. Huang, Z. Yang and R. J. Sawchuk, J. Pharm. Sci.., 91 (1), 217-28 (2002).

13- Glaxo Inc. Zantac (Ranitidine Hydrochloride) Tablets, Geldose Capsules, Effervescent Dose Tablets, Granules and Syrup Prescribing Information. Research Triangle Park, NC. (1999).

14- P. F. Carey, L.E. Martin and P. E. Owen, J. Chromatogr., 225, 161-8 (1981).

15- C. A. Helman and L. O. Tim, Pharmacotherapy, 3, 185-92 (1983).
16- D. Garg, Clin Pharmacol Ther., 33, 445-52 (1983).

17- K. S. Reynolds, M. H. Song, W. D. Heizer, C. B. Burns, D. A. Sica and K. L. Brouwer, Pharm. Res., 15, 1281-5 (1998).

18- R. Miller, J. Pharm. Sci., 733, 1376-9 (1984).

19- T. Gramatte, E. Eldesoky and U. Klotz, Eur. J. Pharmacol., 46 (3), 253-9 (1994).

20- A. B. Suttle and K. L. Brower, Drug Metab. Disp., 22, 224-32 (1993).

21- W. J. Wright and F. Boudinot, Pharm. Res., 13, 1720-4 (1996).

22- G. E. Amidon, N. F. H. Ho, A. B. French and W. I. Higuchi, J. Theo. Biol., 89, 195210 (1981).

23- N. F. H. Ho, H. P. Merkle and W. I. Higuchi, Drug Dev. Ind. Pharm., 9 (7), 1111-1184 (1983).

24- N. F. H. Ho, J. Y. Park, P. F. Ni and W. I. Higuchi, "Advancing Quantitative and mechanistic Approaches in Interfacing Gastrointestinal Drug Absorption Studies in Animals and Humans", In W. Crouthamel and A. C. Sarapu (Eds.), "Animal Models for Oral Drug Delivery in Man: In situ and In vivo Approaches", American Pharmaceutical Association Academy of Pharmaceutical Sciences, Washington, DC., 1983, pp. 27-106.

25- N. Lifson and A. A. Hakim, Am. J. Physiol., 211 (5), 1137-1146 (1966).

26- N. Lifson, L. M. Gruman and D. G. Levitt, Ibid., 215 (2), 444-454 (1968).

27- E. H. Bresler and L. J. Groome, Ibid., 241, F 469-F 476 (1981).

28- P. Schaiquevich, A. Niselman and M. Rubio, Pharmacological Research, 45 (5), 399-405 (2002).

29- A. B. Suttle and K. L. Brouwer, Pharm. Res., 12 (9),1316-22 (1995)

30- M. Hayashi, T. Sawada, M. Tomita, T. Horie and S. Awazu, "Significance of paracellular Pathway in Intestinal Drug Absorption", Fourth European Congress of Biopharmaceutics and Pharmacokinetics, 1990, Abstract, p. 408.

31- J. R. Pappenheimer and K. Z. Reiss, J. Membr. Biol., 100, 123-136 (1987).

32- H. Ochsenfahrt and D. Winne, NaunynSchmiedeberg Arch. Pharmacol., 281, 197-217 (1974). 
33- H. Ochsenfahrt and D. Winne, NaunynSchmiedeberg Arch. Pharmacol., 281, 175-196 (1974).

34- C. G. Wilson and N. Washington, "Physiological Pharmaceutics: Biological Barriers to Drug Absorption", Ellis Horwood Limited, Chichester, England, 1989, pp. 71-90.

35- I. Komiya, J. Y. Park, A. Kamani, N. F. H. Ho. and W. I. Higuchi, Int. J. Pharm., 4, 249-262 (1980).

36- L. S. Gan, P. H. Hsyu, J. F. Pritchard and D. Thakker, Pharm. Res., 10 (12), 1722-5 (1993).
37- V. Mummaneni and J. B. Dressman, Pharm. Res., 11 (11),1599-604 (1994).

38- J. M. Mariadason, D. Kilias, A. CattoSmith and P. R. Gibson, J. Gastroenterol Hepatol., 14 (9), 873-9 (1999).

39- S. Vidyasagar and B. S. Ramakrishna, J. Physiol., 15, 539 (pt 1), 163-73 (2002).

40- G. H. Rabbani, M. J. Albert, H. Rahman and A. K. Chowdhury, Dig. Dis. Sci., 44 (8), 1547-53 (1999). 